\title{
PENGEMBANGAN MODEL TALKING STICKS DALAM KETERAMPILAN BERBICARA BAHASA INGGRIS PADA SISWA KELAS X (IPA 1) DI SMAN 4 BANGKALAN- MADURA
}

\author{
Moh. Arief Wahyudi \\ STKIP PGRI Bangkalan, Madura \\ Email: arwah74@gmail.com
}

\begin{abstract}
Abstrak. Ada model pembelajaran yang bisa membantu guru kelas $\mathrm{X}$ di sekolah menegah atas dalam bidang studi bahasa Inggris yaitu model dengan menggunakanTalking Sticks.Peneliti menggunakan metode Descriptif Kualitatif dengan instrument observasi check list sebanyak tiga kali pertemuan maka data yang dihasilkan bahwa jumlah total skore pada jawaban "yes" berjumlah 9 dan "no" berjumlah 0 dengan jumlah indikator 9. Dan di simpulkan siswa kelas X (IPA 1) di SMAN 4 sukses dalam menggunakan Talking Sticks untuk mengungkapkan opininya/ gagasan dengan menggunakan bahasa Inggris.Maka Pengembangan model tersebut pada pembelajaran bidang studi Bahasa Inggris khususnya keterampilan berbicara telah berhasil diterapkan didalam kelas dalam bentuk diskusi serta dapat memperbaiki speaking siswa.
\end{abstract}

\section{Kata kunci: Model Talking Sticks, Pengembangan}

Abstract. There is a learning model that can help teachers in class X of Senior high schools in the field of study of the English language namely a Talking Sticks Model. The researchers used a Descriptive Qualitative method with the instrument of observation check list by three meeting times. Generated data that the total number of scores on the answer "yes" numbered 9 and "no" numbered 0 . The number of indicators was 9 and concluded class X (IPA 1) SMAN 4 was success by using Talking Sticks to express his opinions / ideas in the English language. Then the model development in this study of learning English speaking skills a particular have been successfully applied in at classroom in the form of discussion and can improve students' speaking skill.

Keywords: Talking Sticks Model, Development

\section{PENDAHULUAN}

Dalam pelaksanaan pembelajaran, salah satu masalah yang sering dijumpai adalah kurangnya keaktifan siswa. Faktor penyebab tersebut bisa berasal dari diri siswa dan dapat pula bersumber dari guru. Untuk itu guru harus mencari tahu apa faktor penyebabnya. Guru harus introspeksi diri, jangan asal menyalahkan siswa. Setelah mengetahui faktor penyebabnya, langkah selanjutnya guru harus mampu mengupayakan peningkatan keaktifan siswa dengan menerapkan berbagai strategi metode maupun media yang sesuai dengan kondisi dan karakteristik siswa.

Dalam pelajaran bahasa Inggris, ada empat keterampilan yang harus dikuasai yaitu membaca, berbicara, mendengarkan dan menulis. Keempat keterampilan tersebut terintegrasi dan terkait satu sama lain. Hal ini telah diajarkan oleh setiap sekolah sehingga semua siswa harus memahaminya. Dalam mengembangkan kemahiran berbicara, seseorang perlu berkomunikasi dengan yang 
lain serta harus aktif dalam kehidupan seharihari, ketika kita tidak mencoba maka tidak terwujud. Fakta menyatakan, bahwa tidak semua siswa memahami kemampuan dalam keterampilan berbicara dengan menggunakan bahasa Inggris.Dalam hal ini, peneliti mencoba mengadakan pengamatan di setiap sekolah khususnya siswa kelas X (IPA 1) di SMAN 4 Bangkalan. Mereka tidak mengetahui bagaimana ketrampilan berbicara dalam bahasa Inggris, memahami dan mengungkapkan pendapat/ide dalam berkomunikasi. Setelah dilakukan observasi ternyata yang menjadi akar permasalahan penyebab ketidakaktifan siswa adalah karena guru masih menerapkan metode konvensional dalam pelaksanaan pembelajaran. Akibatnya siswa cenderung bosan dan merasa tidak senang. Dalam memecahkan masalah ini peneliti mencoba untuk membantu dengan menggunakan model pembelajaran yaitu Talking Sticks atau tongkat berbicara. Pengembangan dan penerapan metode Talking Stick diharapkan mampu menjadikan suasana pembelajaran yang lebih menarik dan menyenangkan serta dapat meningkatkan keaktifan siswa. Dalam pelaksanaan pembelajaran dengan penerapan metode tersebut, siswa harus selalu siapa dan sigap. Siswa dituntut untuk berani mengemukakan pendapatnya. Siswa juga harus dapat berlatih disiplin dengan mengikuti aturan yang berlaku dalam pelaksanaan pembelajaran.
Dengan demikian diharapkan tidak ada siswa yang pasif.

Tujuan khusus dari penelitian ini adalah a. Menjelaskan penerapan model pembelajaran talking sticks dalam keterampilan berbicara bahasa Inggris khususnya siswa KelasX di BangkalanMadura, b. Mengetahui respon siswa terhadap model pembelajaran talking sticks khususnya siswa Kelas X (IPA 1)diSMAN 4 Bangkalan- Madura. Dari pengembangan model tersebut maka muncul suatu pertanyaan yaitu:1. Bagaimanakah penerapan model tersebut terhadap siswa kelas X (IPA 1) di SMAN 4 Bangkalan? 2. Bagaimanakah responds siswa terhadap penerapan model pembelajaran dengan menggunakan Talking Sticks?

Pembelajaran, Ada tiga ciri- cirri khas yang terkandung dalam system pembelajaran oleh Hamdani, 2011: 31-32), yaitu:

1. Rencana ialah penataan ketenagaan, material dan prosedure yang merupakan system pembelajaran dalam suatu rencana khusus

2. Saling ketergantungan antara unsur- unsur system pembelajaran yang serasi dalam suatu keseluruhan

3. Tujuan, system pembelajaran mempunyai tujuan tertentu yang hendak dicapai cirri ini memiliki dasar perbedaan antara system manusia dan alami (naturall). Tujuan utama siswa adalah pembelajaran agar siswa belajar, 
Tujuannya adalah cara yang sticks merupakan metode pembelajaran yang disampaikan guru untuk menyampaikan memanfaatkan tongkat sebaga imedia pelajaran kepada siswa, karena penyampaian pembelajaran.

itu berlangsung dengan interaksi edukatif, metode pembelajaran dapat diartikan sebagai cara yang digunakan untuk dalam mengadakan hubungan dengan siswa saat berlangsungnya pelajaran (Hamdani, 2011: 80)

\section{Talking Sticks}

Talking sticks adalah tongkat berbicara yang telah digunakan kalangan dewan untuk memutuskan siapa yang mempunyai hak untuk berbicara. Pada saat pimpinan rapat mulai berdiskusi dan memhahas masalah ia harus memegang tongkat. Tongkat akan berpindah pada orang lain apabila ia ingin berbcara atau menanggapi.

Metode talking stick adalah sebuah metode pendidikan yang dilaksanakan dengan cara member kebebasan kepada peserta didik untuk dapat bergerak dan bertindak dengan leluasa sejauh mungkin menghindari unsur-unsur perintah sepanjang tidak merugikan bagi peserta didik dengan maksud untuk menumbuhkan dan mengembangkan rasa percaya diri (ZainalAqib, 2013 :26). Metode talking sticks melatih untuk berani berbicara, metode pembelajaran ini menciptakan suasana yang menyenangkan dan membuat siswa lebih aktif dalam proses belajar mengajar. Metode pembelajaran talking

a. Talking sticks sebagai model pembelajaran

Talking Sticks termasuk model pembelajaran kooperatif ini dilakukan dengan bantuan tongkat, siapa yang memegang tongkat wajib menjawab pertanyaan dari gurusetelah siswa mempelajari materi pokok.Menurut Kagan (2000:1)mengatakan bahwa"Belajar kooperatif adalah suatu istilah yang digunakan dalam prosedur pembelajaran interaktif, dimana siswa belajar bersamasama dalam kelompok-kelompok kecil untuk memecahkan berbagai masalah".Setiap siswa tidak hanya menyelesaikan tugas individunya, tetapi juga berkewajiban membantu tugas teman kelompoknya, sampai semua anggota kelompok memahami suatu konsep.

Model Pembelajaran Talking Sticksini adalah sebuah Model Pembelajaran yang dilaksanakan dengan cara memberi kebebasan kepada peserta didik untuk dapat bergerak dan bertindak dengan leluasa sejauh mungkin menghindari unsur-unsur perintah dan keharus paks aan sepanjang tidak merugikan bagi peserta didik dengan maksud untuk menumbuhkan dan mengembangkan rasa percaya diri. 
Selain melatih berbicara dan juga menciptakan suasana yang menyenangkan dan membuat siswa aktif.

Adapun langkah-langkah penerapan Model Pembelajaran Talking Stick menurut Suyatno (2009:124) adalah:

1. Guru menyiapkan sebuah tongkat, guru menyampaikan materi pokok yang akan dipelajari, kemudian memberikan kesempatan kepada peserta didik untuk membaca dan mempelajari materi pada pegangan/paketnya.

Setelah selesai membaca buku dan mempelajarinya, guru mempersilahkan peserta didik untuk menutup bukunya.

2. Guru mengambil tongkat dan memberikan kepada peserta didik, setelah itu guru memberikan pertanyaan dan pese rta didik yang memegang tongkat tersebut harus menjawabnya, dem ikian seterusnya sampai sebagian besar peserta didik mendapat bagian untuk menjawab setiap pertanyaan dari guru.

3. Guru memberikan kesimpulan.

4. Guru melakukan evaluasi

5. Guru melakukan penutupan pembelajaran Langkah-langkah penerapan yang lainnya menurut (Agus Suprijono,2009:109) sebagai berikut:

1. Guru membentuk kelompok yang terdiri atas 5 orang
2. Menyiapkan tongkat sepanjang $15 \mathrm{~cm}$

3. Guru menyampaikan materi pelajaran, kemudian memberikan kesempatan para kelompok untuk membaca dan mempelajari meteri

4. Siswa berdiskusi untuk membahas masalah yang terdapat dalam wacana

5. Setelah kelompok selesai membaca materi pelajaran dan mempelajari isinya, guru mempersilakan anggota kelompok untuk menutup isi bacaan

6. Guru Mempersiapkan tongkat dan memberikan kepada salah satu anggota kelompok, setelah itu guru memberi pertanyaan dalam anggota kelompok yang memegang tongkat tersebut harus menjawabnya. Demikian seterusnya sampai sebagian besar siswa mendapatkan bagian untuk menjawab setiap pertanyaan dari guru

7. Siswa lain boleh membantu menjawab pertanyaan jika anggota kelompoknya tidak menjawab pertanyaan

8. Guru memberikan kesimpulan

9. Guru melakukan evaluasi/ penilaian, baik secara kelompokmaupun individu

10. Guru menutup pelajaran

\section{b. Tujuan Model Pembelajaran Talking Stick}

Metode Talking Sticks termasuk dalam pembelajaran kooperatif karena memiliki ciri-ciri yang sesuai dengan pembelajaran kooperatif yaitu: 
1) Siswa bekerja dalam kelompok secara kooperatif untuk menuntaskan materi belajarnya.

2) Kelompok dibentuk dari siswa yang memiliki kemampuan tinggi, sedang dan rendah.

3) Bilamana mungkin, anggota kelompok berasal dari ras, budaya, suku, jenis kelamin yang berbeda.

4) Penghargaan lebih berorientasi kelompok ketimbang individu.

\section{Manfaat Talking Sticks}

MenurutWina Sanjaya (2007:cet. Ke-

3) manfaat Talking Sticks yaitu:

1. Menguji kesiapan siswa

2. Melatih memahami dengan cepat

3. Melatih untuk berbicara dengan cara mengekpresikan sesuai pengetahuan siswa tentang masalah
4. Melatih mencoba mencari penyelesaian dari masalah pertanyaan dari guru

5. Membuat siswa ceria, senang dan melatih mental untuk siap dalam kondisi apapun

6. Membuat lebih giat belajar

\section{Aspek yang di nilai dalam keterampilan} berbicara

Dalam hal ini pembelajaran model Talking Sticks menggunakan penilaian sebagai berikut;

1. Aspek perbendaharaan kata (vocabulary),

2. Aspek kecakapan dalam pemahaman (comprehension)

3. Aspek kelancaran (fluency)

4. Aspek logat (accent) dan

5. Aspek gramatikal (grammar)

Rubrik penilaian Nunan (1994)

\begin{tabular}{|l|c|c|c|c|c|c|}
\hline Proficiency description & $\mathbf{1}$ & $\mathbf{2}$ & $\mathbf{3}$ & $\mathbf{4}$ & $\mathbf{5}$ & $\mathbf{6}$ \\
\hline Accent & 0 & 1 & 2 & 2 & 3 & 4 \\
\hline Grammar & 6 & 12 & 18 & 24 & 30 & 36 \\
\hline Vocabulary & 4 & 8 & 12 & 16 & 20 & 24 \\
\hline Fluency & 2 & 4 & 6 & 8 & 10 & 12 \\
\hline Comprehension & 4 & 8 & 12 & 15 & 19 & 23 \\
\hline
\end{tabular}

\section{Kreteria penilaian}

\section{Logat (Accent)}

6 : Penutur asli

5 : Mudah dipahami dan memiliki aksen penutur asli
4 : Mudah dipahami meskipun dengan aksen tertentu

3 : Ada masalah pengucapan yang membuat pendengar harus konsentrasi penuh dan kadang- kadang ada kesalahpahaman 
2 : Sulit dipahami karena ada masalah pengucapan, sering diminta mengulang

1: Masalah pengucapan serius sehingga tidak bisa dipahami

\section{Gramatikal (Grammar)}

6 : Tidak ada kesalahan

5 : Tidak ada atau sedikit kesalahan tata bahasa

4 : Kadang-kadang membuat kesalahan tata bahasa tetapi tidak mempengaruhi makna

3 : Sering membuat kesalahan tata bahasa yang mempengaruhi makna

2 : Banyak kesalahan tata bahasa yang menghambat makna dan sering menata ulang kalimat

1 : Kesalahan tata bahasa begitu parah sehingga sulit dipahami

\section{Kosa-kata (Vocabulary)}

6 : Penutur asli

5 : Menggunakan kosa kata dan ungkapan seperti penutur asli

4 : Kadang-kadang menggunakan kosa kata yang tidak tepat

3 : Sering menggunakan kosa kata yang tidak tepat, percakapan menjadi terbatas karena keterbatasan kosa kata

2 : Menggunakan kosa kata secara salah dan kosa kata terbatas sehingga sulit dipahami

1 : Kosa kata sangat terbatas sehingga percakapan tidak mungkin terjadi

\section{Kelancaran (Fluency)}

6 : Tidak ada masalah sedikitpun

5 : Kelancaran tampak sedikit terganggu oleh masalah bahasa
4 : Kelancaran agak banyak terganggu oleh masalah bahasa

3 : Lancar seperti penutur asli

2 : Sering ragu-ragu dan terhenti karena keterbatasan bahasa

1 : Bicara terputus-putus dan terhenti sehingga percakapan tidak mungkin terjadi

\section{Kecakapan (Comprehension)}

6 : Memahami semua tanpa mengalami kesulitan

5 : Memahami semuanya, walau ada pengulangan pada bagian tertentu

4 : Memahami hampir semuanya, walau ada pengulangan pada bagian tertentu

3 : Memahami sebagian besar apa yang dikatakan bila bicara agak diperlambat walau ada pengulangan

2 : Tidak bisa memahami walaupun percakapan sederhana

: Susah mengikuti apa yang dikatakan.

\section{METODE}

Berkaitan dengan latar belakang penelitian, penelitian ini menggunakan Penelitian diskriptif kualitatif karena tujuan dari penelitian ini adalah untuk menemukan solusi terhadap permasalahan yang terjadi dikelas.Dalam penelitian ini peneliti, menggunakan pendekatan kualitatif. Pendekatan kualitatif digunakan untuk mendeskripsikan proses pembelajaran berbicara (speaking skill) melalui metode Talking Sticks. Untuk mengetahui peningkatan kemampuan berbicarasiswa, 
peneliti menggunaka pensekoran (scoring rubric) yang terdapat ada bab II untuk mengukurnya.

Subjek penelitian ini adalah siswa kelasX (IPA I) di SMAN 4 Bangkalan yang dimana terdapat 30(tiga puluh) siswa dikelas tersebut, peneliti memilih kelas ini karena kelasnya heterogen. Dalam penelitian ini, terdapat beberapa langkah yang akandilakukan pada instrument observasi/ pengamatandengan menggunakan check list yang dilakukan 3 kali , yaitu:

1. Peneliti masuk ke dalam ruangan kelas dan duduk di belakang siswa

2. Peneliti mengamati kegiatan guru dan siswa dalam proses belajar- mengajar dikelas

3. Peneliti menggunakan draft/ table observasi dengan check list

4. Peneliti menganalisa data dengan menyimpulkan hasil dari pengamatan dikelas

\section{HASIL DAN PEMBAHASAN}

1. Sebelum Penerapan Model Talking Sticks

Sebelum mengambil data, peneliti mengadakan observasi pertamapada tanggal 08 November 2016, untuk mencari informasi terlebih dahulu tentang metode yang di pakai oleh guru pengajar bidang studi Bahasa Inggris khususnya yang berhubungan dengan keterampilan berbicara di dalam proses belajar mengajar dan ijin dari pihak sekolah.
Setelah mendapatkannya maka peneliti sudah bisa mengadakan penelitian di sekolah tersebut.Dalam observasi kedua pada tanggal 10 November 2016, Metode yang di pakai guru yaitu menggunakan metode Kooperative yaitu berupa diskusi kelompok yang dimana terdiri dari 5 anggota pada tiaptiap kelompok untuk membahas suatu topikyang berjudul "Mobile Phone" dalam materi pelajaran Bahasa Inggris (lihat appendik I). Jumlah siswa kelas X (IPA 1) adalah 30 siswa dan ada 6 kelompok. Maka dari hasil data yang didapat diatas bisa di simpulkan bahwa sebelum penerapan Talking Sticks, peneliti menemukan beberapa permasalahan dalam keterampilan berbicara pada siswa kelas X (IPA 1)di SMAN 4Bangkalan yaitumasih lemahnya siswa dalam berbicara menggunakan bahasa Inggris, Dari hasil pengamatan observasi pertama dengan menggunakan check list yaitu jumlah total skore pada jawaban "yes" berjumlah 5 dan "no" berjumlah 4 dengan jumlah indikator yang dipakai 9.Hal ini dikarenakan siswa kurang/ tidak siap untuk mengungkapkan/ mengekspresikan ide- ide/ gagasan tentang topic yang di berikan oleh guru saat diskusi kelompok berlangsung, Permasalahan diatas tersebut juga berkaitan dengan aspek-aspek penilaian dalam Speaking skill.Aspek pertama adalah logat (accent), peneliti menemukan3 siswa yang nilai aspek logatnya 1 (satu), 14 siswa yang mendapatkan nilai 4 (empat), 11 siswa yang 
mendapatkan nilai 3 (tiga). Aspek kedua adalah gramar (grammar),2 siswa yang mendapatkan nilai 6 (enam), 5 siswa yang mendapatkan nilai 12 (duabelas), 15 siswa mendapatkan nilai 18 (delapan belas) dan 7 siswa mendapatkan 24 (dua empat).

Aspek ketiga, kosa-kata

(Vocabulary), penguasaan kosa-kata siswa bermacam-macam, terdapat 4 siswa yang mendapatkan nilai 8 (delapan), 12 siswa yang mendapatkan nilai 16 (enam belas), 12 siswa yang mendapatkan nilai 20 (dua puluh) dan 2 siswa mendapatkan24 (dua empat). Aspek keempat adalah kelancaran (fluency), terdapat 1 siswa mendapatkan nilai 4 (empat), 2 siswa yang mendapatkan nilai 6 (enam), 6 siswa yang mendapatkan nilai 12 (dua belas) dan 15 siswa mendapatkan 10 (sepuluh). Sedangkan aspek yang terakhir adalah kecakapan (comprehension), terdapat 4 siswa yang mendapatkan nilai 4 (empat), 3 siswa yang mendapatkan nilai 8 (delapan), 1 siswa yang mendapatkan nilai 12 (dua belas), 12 siswa mendapatkan 15 (lima belas), 10 siswa mendaatkan 1(satu) dan 2 siswa mendapatkan 23(dua puluh tiga).

\section{Setelah Penerapan Model Talking} Sticks

Dari hasil pemaparan diatas bahwa keterampilan berbicara siswa kelas $\mathrm{X}$ (IPA 1) masih lemah.Dalam mengatasi permasalahan tersebut maka peneliti mencoba untuk berdiskusi dengan guru pengajar bahasa Inggris tentang metode Talking Sticks, karena dengan metode ini maka siswa akan selalu siap untuk memaparkan ide- ide/ gagasan yang sesuai dengan topik yang diajarkan. Dari hasil pengamatan yang ketiga pada tanggal 17 November 2016, peneliti mendapatkan data dan menganalisanya yaitu jumlah total skore pada jawaban "yes" berjumlah 9 dan "no" berjumlah 0 dengan jumlah indikator 9 .

Aspek pertama adalah logat (accent), peneliti menemukan14 siswa yang nilai aspek logatnya 3 (tiga), 11 siswa yang mendapatkan nilai 2 (dua), 5siswa yang mendapatkan nilai 4 (empat). Aspek kedua adalah gramar (grammar), 21siswa yang mendapatkan nilai 24 (dua empat), 7siswa yang mendapatkan nilai 18 (delapan belas),2 siswa mendapatkan nilai 30 (tiga puluh). Aspek ketiga, kosa-kata (Vocabulary), penguasaan kosa-kata siswa, terdapat 19 siswa yang mendapatkan nilai 20 (dua puluh), 11 siswa yang mendapatkan nilai 24 (dua empat), Aspek keempat adalah kelancaran (fluency), terdapat 19siswa mendapatkan nilai 10 (sepuluh), 1siswa yang mendapatkan nilai 8 (delapan), 10siswa yang mendapatkan nilai 12 (dua belas). Sedangkan aspek yang terakhir adalah kecakapan (comprehension), terdapat 21siswa yang mendapatkan nilai 19 (Sembilan belas), 1 siswa yang mendapatkan nilai 18 (delapan belas) dan 18siswa yang 
mendapatkan nilai 23 (dua tiga).

Berdasarkan data yang diperoleh maka peneliti mencari penyelesaian masalah pada bab I yang samplenya siswa kelas $\mathrm{X}$ (IPA 1) di SMAN 4 Bangkalan yang berhubungan dengan keterampilan bahasa Inggris yaitu dengan penerapan metode Talking sticks adalah baik sehingga bisa mengatasi siswa yang tidak bisa/kurang aktif berbicara menjadi aktif serta termotivasi untuk berbicara/mengekspresikan ide-ide/ gagasan mereka dalam bahasa Inggris.

Sehingga seorang pakar yang bernama Wina Sanjaya (2007:cet. Ke-3) menjelaskan tentang manfaat Talking Sticks telah terbukti dengan analisis dari penelitian tersebut diatas yaitu:

1. Menguji kesiapan siswa

2. Melatih memahami dengan cepat

3. Melatih untuk berbicara dengan cara mengekpresikan sesuai pengetahuan siswa tentang masalah

4. Melatih mencoba mencari penyelesaian dari masalah pertanyaan dari guru

5. Membuat siswa ceria, senang dan melatih mental untuk siap dalam kondisi apapun

6. Membuat lebih giat belajar

Serta terdapat temuan dari pengembangan

Talking Sticks adalah:

1. Penerapan talking Sticks dapat meningkatkan motivasi belajar dan keaktifan siswa dalam proses pembelajaran bahasa Inggris

2. Penerapan talking Sticks dapat meningkatkan motivasi belajar dan keaktifan siswa secara individu

3. Penerapan talking Sticks dapat menjadikan siswa berperan aktif dalam pembelajaran dan suasana belajar menjadi hidup

\section{SIMPULAN DAN SARAN}

Dari hasil penelitian dengan judul "Pengembangan Model Talking Sticks dalamketerampilan berbicara Bahasa Inggris pada siswa kelas $\mathrm{X}$ (IPA) 1 di SMAN 4 Bangkalan, Madura" maka Pengembangan model tersebut pada pembelajaran bidang studi Bahasa Inggris khususnya keterampilan berbicara telah berhasil diterapkan didalam kelas dalam bentuk diskusi serta dapat memperbaiki speaking siswa. Peningkatan kemampuan berbicara dalam mengungkapkan atau mengekpresikan ideide/ gagasan siswa sangat bagus hal ini di karenakan mereka bisa mengembangkan/ meilustrasikan / mendiskripsikan dengan sendirinya yang didasari pengalaman yang ada dan keaktifan mereka sendiri. Peningkatan tersebut melalui beberapa aspek dalam berbicara, yang paling dominan adalah peningkatan aspek kosa-kata (vocabulary), selanjutnya aspek kecakapan (comprehension) dan kelancaran (fluency), tetapi pada aspek logat (accent) dan gramatikal (grammar) tidak terlalu berpengaruh karena siswa dituntut berfikir dan berkomunikasi dengan cepat. 
Peneliti mempunyai beberapa saran untuk meningkatkan ketrampilan berbicara dalam bahasa Inggris melalui metode Talking Sticks (tongkat berbicara): a) sebagai salah satu rujukan dalam pembelajaran bidang studi bahasa Inggris di tingkat SMA/ MA, b). Pengguna metodeini untuk mengontrol terhadap seluruh aktifitas yang telah direncanakan, c) memperbaiki apa yang menjadi kekurangan metode ini dalam meningkatkan aspek-aspek dalam ketrampilan berbicara.

\section{DAFTAR PUSTAKA}

Burns, A. 2010.Doing Action Research in English Language Teaching: A Guide for Practitioners. New York: Routledge.

Chastain, K, Developing second language skills: theory to practice.USA: University of Virginia.

Cohen, L. \& Manion, L. \& Morrison, K. 2000.Research Methods in Education.Fifth Eddition. London and New York: Routledge/Falmer Taylor and Francis Group.

Cresswell. W. John. 1994. Research Design Qualitative \& Quantitative Approach.Sage publication.

Ellis, R. 2003. Second Language Acquisition. New York: Oxford University Press.

Fromkin,V. Rodman, R. Hiyams, N. 2009. An introduction to language.. New York:Wadsworth.

Nunan, D. 1994, Second language teaching and learning, USA: Heinle
PublisherCok, A. 2000. American accent training.USA: Barons.

Sanjaya, Wina.2007. Strategi Pembelajaran Berorentasi Standar Proses Pendidikan. Jakarta: Kencana

Sugiyono. 2010. Metode Penelitian Kuantitatif Kualitatif dan $R \& D$. Bandung: Alphabeta.

Sugiyono. 2007. Metode Penelitian Pendidikan. Bandung: Bandung.

Supriyono, A. 2009. Cooperative Learning. Pustaka Pelajar. Yogyakarta

Sutikno, M. Sobry, 2014. Metode dan Modelmodel Pembelajaran.Hdistica.Lombok. Mataram

Suyatno. 2009. Penerapan Model Pembelajaran Talking Stick. Pustaka Pelajar. Yogyakarta

Sumber:http//jurnalbidandiah.blogspot.com/ 20112/04/model-pembelajaran talking.sticks.html\#ixzz3z4ftfv9u 